\title{
BIOLOGICAL CHARACTERISTICS OF ROCK GOBY, GOBIUS PAGANELLUS (ACTINOPTERYGII: PERCIFORMES: GOBIIDAE), IN THE SOUTH-EASTERN BLACK SEA
}

\author{
Semih ENGIN ${ }^{1 *}$ and Kadir SEYHAN ${ }^{2}$ \\ ${ }^{1}$ Rize University, Faculty of Fisheries, 53100, Rize, Turkey \\ ${ }^{2}$ Karadeniz Technical University, Faculty of Marine Sciences, Trabzon, Turkey
}

Engin S., Seyhan K. 2009. Biological characteristics of rock goby, Gobius paganellus (Actinopterygii: Perciformes: Gobiidae), in the south-eastern Black Sea. Acta Ichthyol. Piscat. 39 (2): 111-118.

\begin{abstract}
Background. Gobius paganellus L. is one of the most common gobiid fish in the south-eastern Black Sea. The aim of present study is to provide information on age structure and growth, length at sexual maturity, annual cycle of gonad development, and diet of rock goby in the south-eastern Black Sea.

Materials and Methods. One hundred seventy-five specimens of G. paganellus were sampled from two stations in the province of Rize, south-eastern Black Sea. Samplings were performed by free diving using spear gun and hand net at night time. Specimens were dissected and sagittal otoliths, stomachs, livers, and gonads were removed. Otoliths were cleaned, immersed in glycerol, and examined on black background using reflected light at low magnification to determine age. Mean size at sexual maturity $\left(\mathrm{L}_{50}\right)$ (i.e., size at which $50 \%$ of fish are mature) was estimated for males and females by fitting the logistic Gompertz function to the proportion of mature fish per $\mathrm{cm}$ size-class. The gonadosomatic index, seminal vesicle somatic index, and hepatosomatic index were calculated on monthly basis. The quantitative importance of different prey in the diet was assessed by calculating the frequency of occurrence, the percentage number, and the percentage mass of prey. The main food index $\left(I_{\mathrm{MF}}\right)$ was calculated to combine the three used methods $\left(I_{\mathrm{MF}}=(0.5(\% F+\% N) \% W)^{0.5}\right)$.

Results. The maximum age was estimated to be 7 and 6 years for males and females, respectively. The von Bertalanffy growth parameters was estimated from the mean age-length data for males and females (males: $L_{\infty}=13.1 \mathrm{~cm}, k=0.34$, $t_{o}=-0.11$; females: $L_{\infty}=18.2 \mathrm{~cm}, k=0.18, t_{o}=-0.07$ ). The estimated length at sexual maturity was 5.20 and $5.50 \mathrm{~cm}$ for males and females, respectively. The spawning season was between March and May. Total fecundity ranged from 1550 to 5839 eggs/female, with an average of $4322 \pm 1109$ eggs per female. The rock goby feeds on a wide variety of prey items, particularly on gammarids, brachyurans, natantians, bivalves, isopods, and fish. Conclusion. Growth rate $(K)$ and growth performance index $\left(\varphi^{\prime}\right)$, length at sexual maturity, fecundity and feeding habits of Black Sea rock goby differ from Atlantic populations.
\end{abstract}

Keywords: Gobius paganellus, age and growth, reproduction, diet, Black Sea

\section{INTRODUCTION}

The rock goby Gobius paganellus L. is a relative large goby found along the north-western Atlantic, from Scotland to Senegal, the Mediterranean Sea and the Black Sea (Miller 1986, Engin et al. 2007, Fricke et al. 2007). It is a common inshore and intertidal species, inhabiting under stones and in pools on sheltered rocky shores with much weed cover (Miller 1986). Thirty-five gobiid species are known from the Black Sea basin, some of them recorded only recently (Engin et al. 2007, Fricke et al. 2007, Kovačić and Engin 2008). Although there are some studies on this species from Atlantic (Miller 1961, Dunne 1978, Azevedo and Simas 2000) and
Mediterranean areas (Gibson 1972, Mazé 2004), no information is currently available on biology and ecology from the Black Sea population. The aim of this study, therefore, is to investigate various aspects of biology of Gobius paganellus from the Black Sea.

\section{MATERIALS AND METHOD}

One hundred seventy-five specimens of G. paganellus were sampled from two stations in the province of Rize, south-eastern Black Sea (Fig. 1), from January to December 2005. Samplings were performed between 1-10 $\mathrm{m}$ depth by free diving, using spear gun and hand net at night time. The water temperature was measured at $3 \mathrm{~m}$

\footnotetext{
* Correspondence: Dr. Semih Engin, Rize University, Faculty of Fisheries, 53100, Rize, Turkey, phone: +90-5427314281, fax: +90-4642234118, e-mail: engin.semih@gmail.com
} 
depth, i.e., where the most specimens were sampled. Fish were immediately fixed in $70 \%$ alcohol and transferred to the laboratory.

Total length of each individual was measured to $0.1 \mathrm{~mm}$ (then they were grouped into $10 \mathrm{~mm}$ size classes) and wet mass was recorded to the nearest $0.001 \mathrm{~g}$ after blotting dry on absorbent paper. The specimens were dissected and sagittal otoliths, stomachs, livers, and gonads were removed. Otoliths were cleaned, immersed in glycerol, and examined on black background using reflected light at low magnification to ageing fish (Miller 1961). The von Bertalanffy growth function was fitted to the length-atage data using non-linear least squares estimation procedures (Ricker 1975).

Sex was assessed and wet mass of the gonads and liver was recorded to the nearest $0.1 \mathrm{mg}$ after blotting dry on absorbent paper. In males, testes and seminal vesicles were weighed separately. The ripe ovaries were used to calculate fecundity. A portion of ovaries was weighed and the oocytes were counted to estimate total fecundity $(F=$ mass of the entire ovaries $\times$ mass of the counted sub- sample $^{-1} \times$ number of oocytes in subsample). Oocyte length (maximum diameter) was measured with digital calliper under a stereomicroscope. Mean size at sexual maturity $\left(\mathrm{L}_{50}\right)$ (i.e., size at which $50 \%$ of fish are mature) was estimated for males and females by fitting the logistic Gompertz function to the proportion of mature fish per $\mathrm{cm}$ size-class. The gonadosomatic index (GSI = gonad mass $\times 100 \times$ body mass $^{-1}$ ), seminal vesicle somatic index $\left(\right.$ SVSI $=$ seminal vesicle mass $\times 100 \times$ body mass $\left.^{-1}\right)$ (Patzner et al. 1991) and hepatosomatic index (HSI = liver

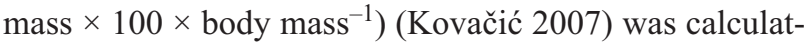
ed on monthly basis.

Stomach contents were sorted according to relevant taxonomic group. Sorted prey items were weighed wet to the nearest $10 \mu \mathrm{g}$ after blotting dry on absorbent paper. The quantitative importance of different prey in the diet was analyzed as follows: percentage frequency of occurrence $(\% F$, the percentage of stomachs in which a certain item occurs in relation to all stomachs containing food); percentage number $(\% N$, each prey item as percentage of total number of food items in the sample); percentage

Diet spectrum of Gobius paganellus in the south-eastern Black Sea

Table 1

\begin{tabular}{lrccc}
\hline Prey & $\% F$ & $\% N$ & $\% W$ & $I_{\mathrm{MF}}$ \\
\hline Alge & 1.2 & 0.3 & 7.1 & 2.3 \\
Bivalvia & 1.8 & 4.1 & 4.3 & 3.5 \\
Gammaridae & 65.3 & 77.3 & 31.4 & 47.3 \\
Brachyura & 8.6 & 2.4 & 17.8 & 9.8 \\
Mysidacea & 3.1 & 2.1 & 2.6 & 2.6 \\
Natantia & 12.2 & 4.3 & 14.4 & 10.8 \\
Isopoda & 3.7 & 1.1 & 5.3 & 3.5 \\
Decapoda larvae & 5.6 & 6.1 & 2.7 & 3.9 \\
Polychaeta & 1.1 & 0.8 & 1.3 & 1.1 \\
Ostracoda & 2.4 & 1.2 & 0.2 & 0.6 \\
Nematoda & 0.5 & 0.4 & 0.8 & 0.6 \\
Pisces & 1.5 & 0.3 & 12.1 & 0.3 \\
\hline
\end{tabular}

$\% F$ : frequency of occurrence; $\% N$ : percentage number; $\% W$ : percentage mass; and $I_{\mathrm{MF}}$ : main food index.

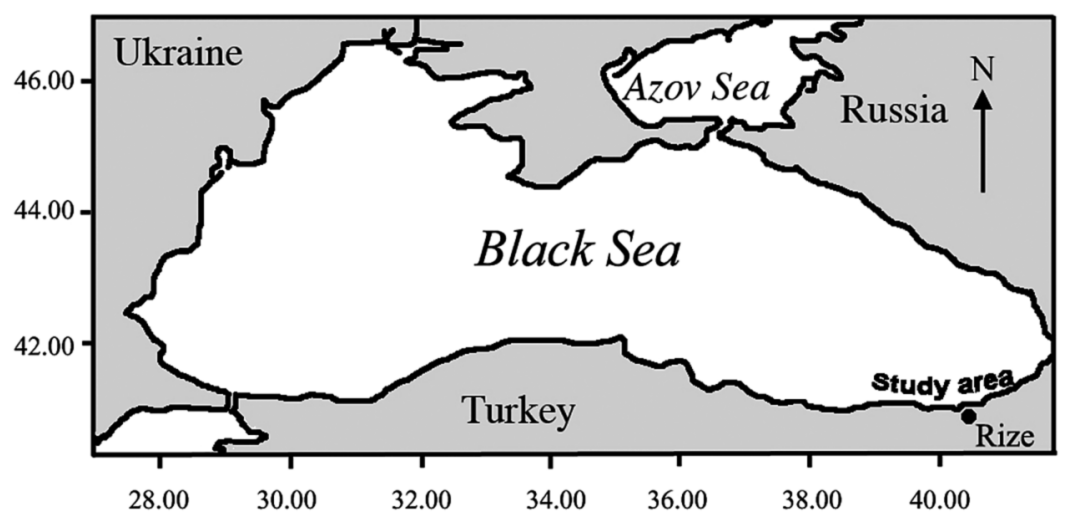

Fig. 1. Study area of Gobius paganellus in the south-eastern Black Sea 
mass $(\% W$, the wet mass of each prey item, as a percentage of total weight of stomach contents). The main food index $\left(I_{\mathrm{MF}}\right)$ was calculated combining the three used methods $\left(I_{\mathrm{MF}}=(0.5(\% F+\% N) \% W)^{0.5}\right)$ (Zander 1982, Kovačić 2001, 2007). The ontogenetic shift in diet was examined comparing the main food index between fish size classes. Feeding intensity was estimated using fullness index $\left(I_{F}=100 W_{\mathrm{GC}} W^{-1}\right)$ (Hureau 1970).

Data analyses were performed using the Excel and Statistica 6.1 software packages.

\section{RESULTS}

Between eleven and twenty-three specimens were collected each month, the minimum being in August, because of the difficulties in sampling rock gobies due to their high activity in summer. The size range of fish was from 5 to $14.1 \mathrm{~cm}$ in males and from $5.1-12.2 \mathrm{~cm}$ in females (Fig. 2). In total 175 specimens were examined, of which 78 were males and 97 females. The sex ratio was not significantly different from unity $\left(\chi^{2}=1.1664\right.$, $P=0.280, P>0.05)$.
Age and growth. All specimens were aged successfully. The maximum estimated age was 7 years for males and 6 years for females, respectively (Fig. 3). The von Bertalanffy growth parameters were calculated for males $\left(L_{\infty}=13.1 \mathrm{~cm}, \mathrm{k}=0.34, \mathrm{t}_{\mathrm{o}}=-0.11\right)$ and for females $\left(L_{\infty}=13.8 \mathrm{~cm}\right.$, $\left.\mathrm{k}=0.29, \mathrm{t}_{\mathrm{o}}=-0.13\right)$. The growth performance index was similar in both sexes (for males $\varphi^{\prime}=3.70$ and for females $\left.\varphi^{\prime}=3.73\right)$.

Reproduction. Length at sexual maturity was estimated for males at $L_{50}=5.20 \mathrm{~cm} \pm 0.19\left(r^{2}=0.99\right)$ and for females at $L_{50}=5.50 \mathrm{~cm} \pm 0.05\left(r^{2}=0.99\right)$ (Fig. 4). In both sexes gonad development started in the first year of life and all specimens were mature at two years of age. Gonadosomatic index (GSI) of females (Fig. 5a) changed significantly throughout months (H Kruskal-Wallis = 189.1, $P<0.001)$ as did male GSI $(\mathrm{H}$ Kruskal-Wallis $=122.5$, $P<0.001)$ and seminal-vesicle-somatic index (SVSI) (H Kruskal-Wallis $=81.2, P<0.001)$ (Figs. 5b and 5c). Ripe males and females were already observed in February. However, GSI peaked in March in both sexes. The spawning season occurs from March to June, when

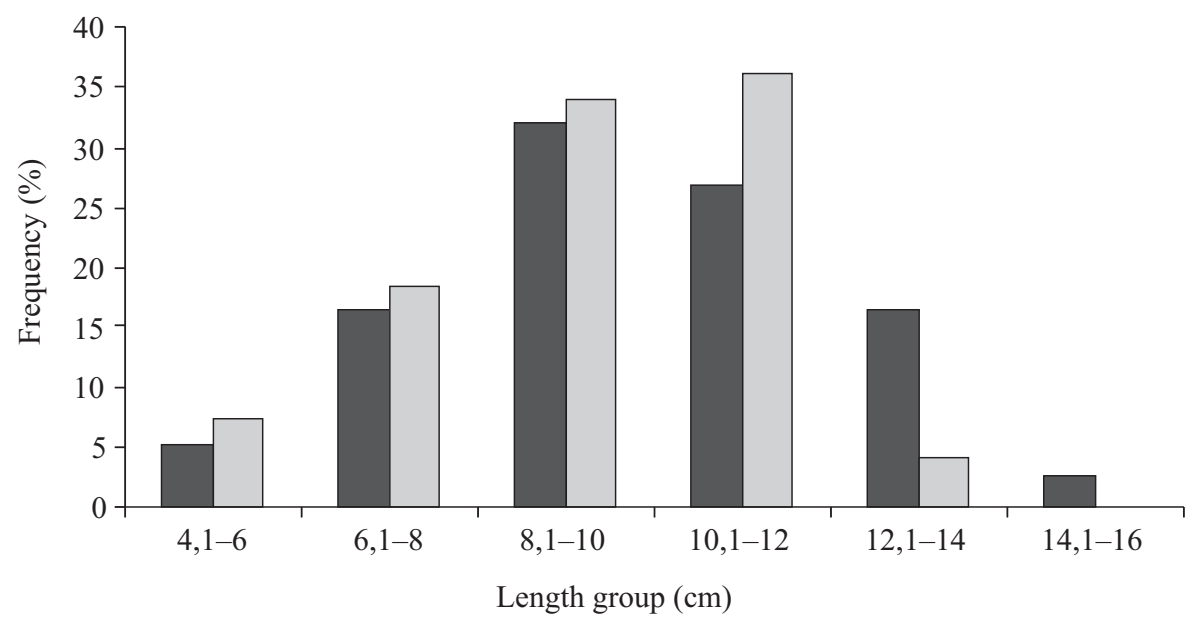

Fig. 2. Length-frequency distribution of male $(\square)$ and female $(\square)$ Gobius paganellus from the south-eastern Black Sea

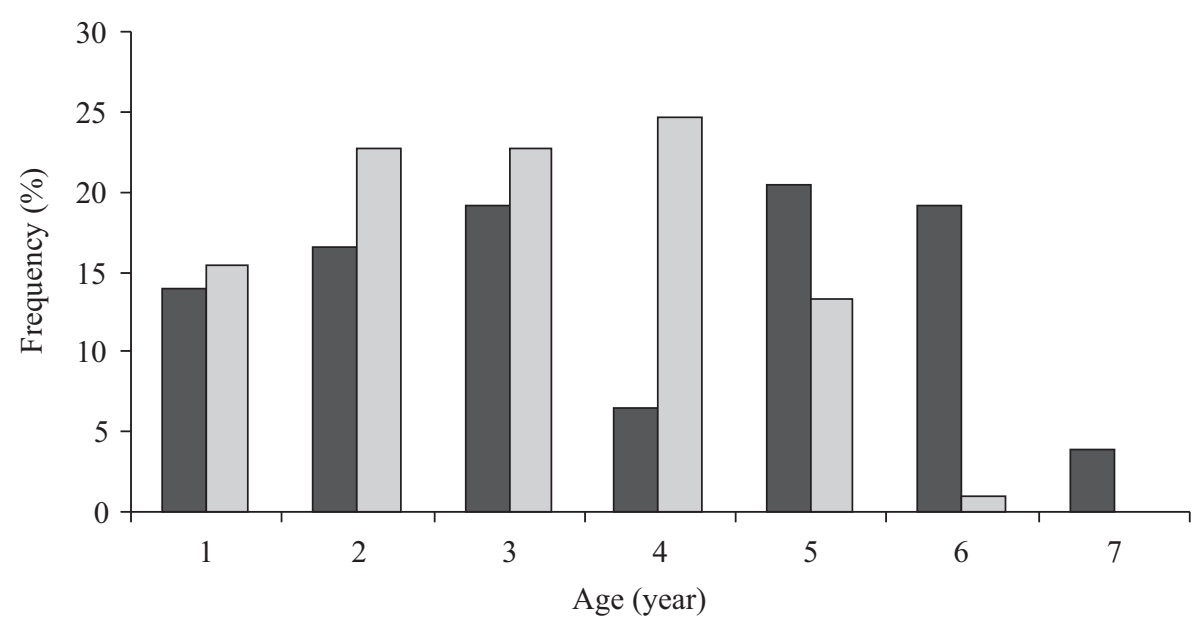

Fig. 3. Age-frequency distributions for male and female $(\square)$ Gobius paganellus from the south-eastern Black Sea 

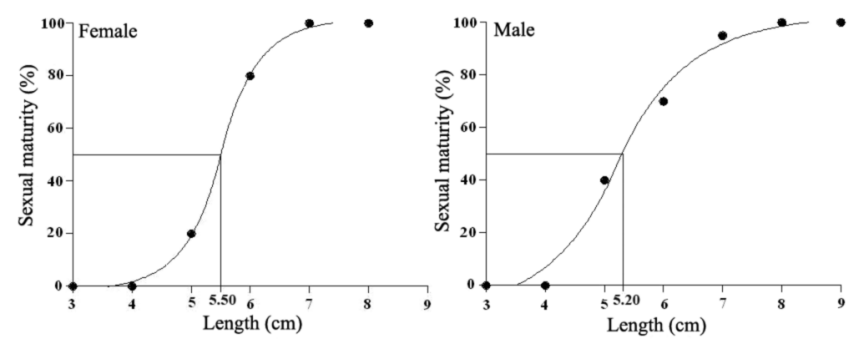

Fig. 4. Length at sexual maturity $\left(L_{50}\right)$ of Gobius paganellus from the south-eastern Black Sea

a

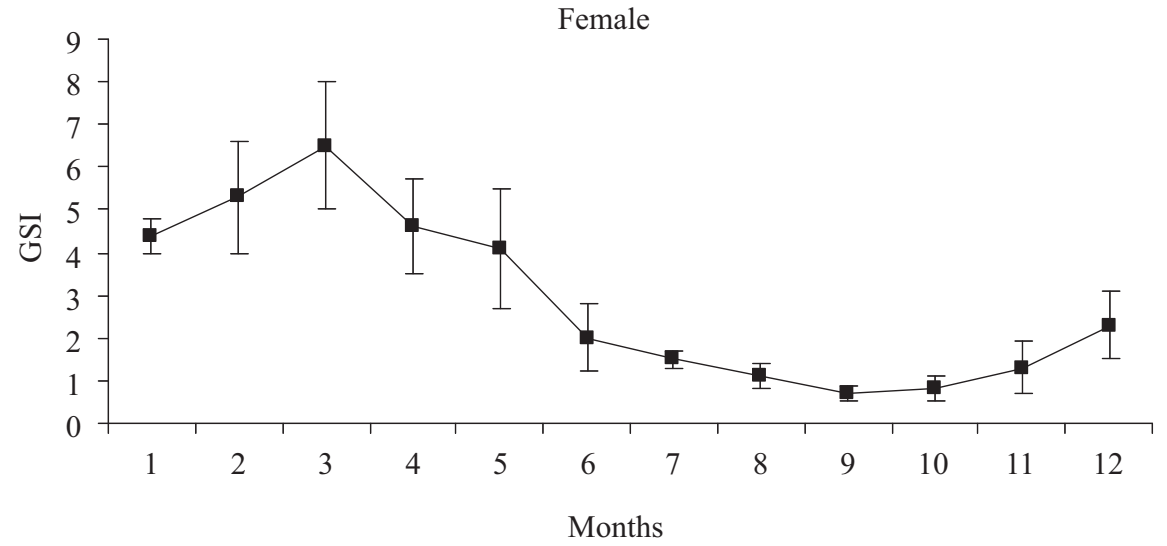

Male

b
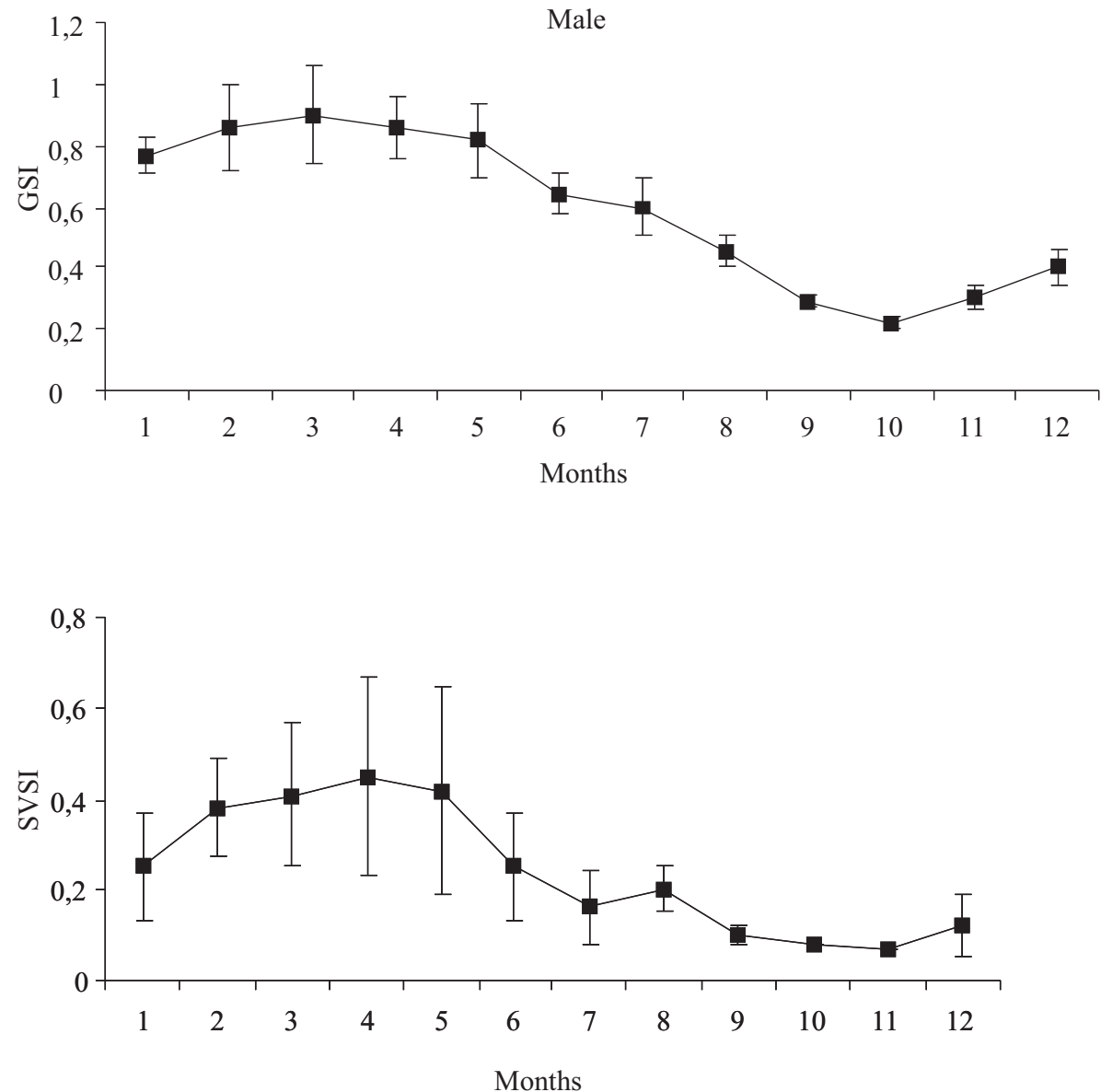

Fig. 5. Monthly gonadosomatic index (GSI) of (a) female and (b) male and (c) seminal vesicle somatic index (SVSI) of Gobius paganellus from the south-eastern Black Sea (Mean \pm SE) 
ripening fish of both sexes were found. In the post spawning period (from July to October), GSI and SVSI reached their lowest value.

Hepatosomatic index (HSI) of both sexes showed a clear seasonal pattern (male; H Kruskal-Wallis $=63.2$, $P<0.001$, female; H Kruskal-Wallis $=45.3, P<0.001)$. It showed a peak in January, and then decreased during the spawning season (Fig. 6a, b).
Fecundity was estimated on 33 ripe females from 6.6 to $13.7 \mathrm{~cm}$ TL. Total fecundity ranged from 1550 to 5839 eggs per fish, with an average of $4322 \pm 1109$ eggs per fish. There was a significant positive relationship between fecundity and fish length (Fig. 7). Ripe oocyte diameters ranged from 0.55 to $0.81 \mathrm{~mm}$, with an average of $0.69 \pm 0.10 \mathrm{~mm}$.

Diet. The stomach contents of G. paganellus contained 12 taxa of food organisms (Table 1). Gammaridae
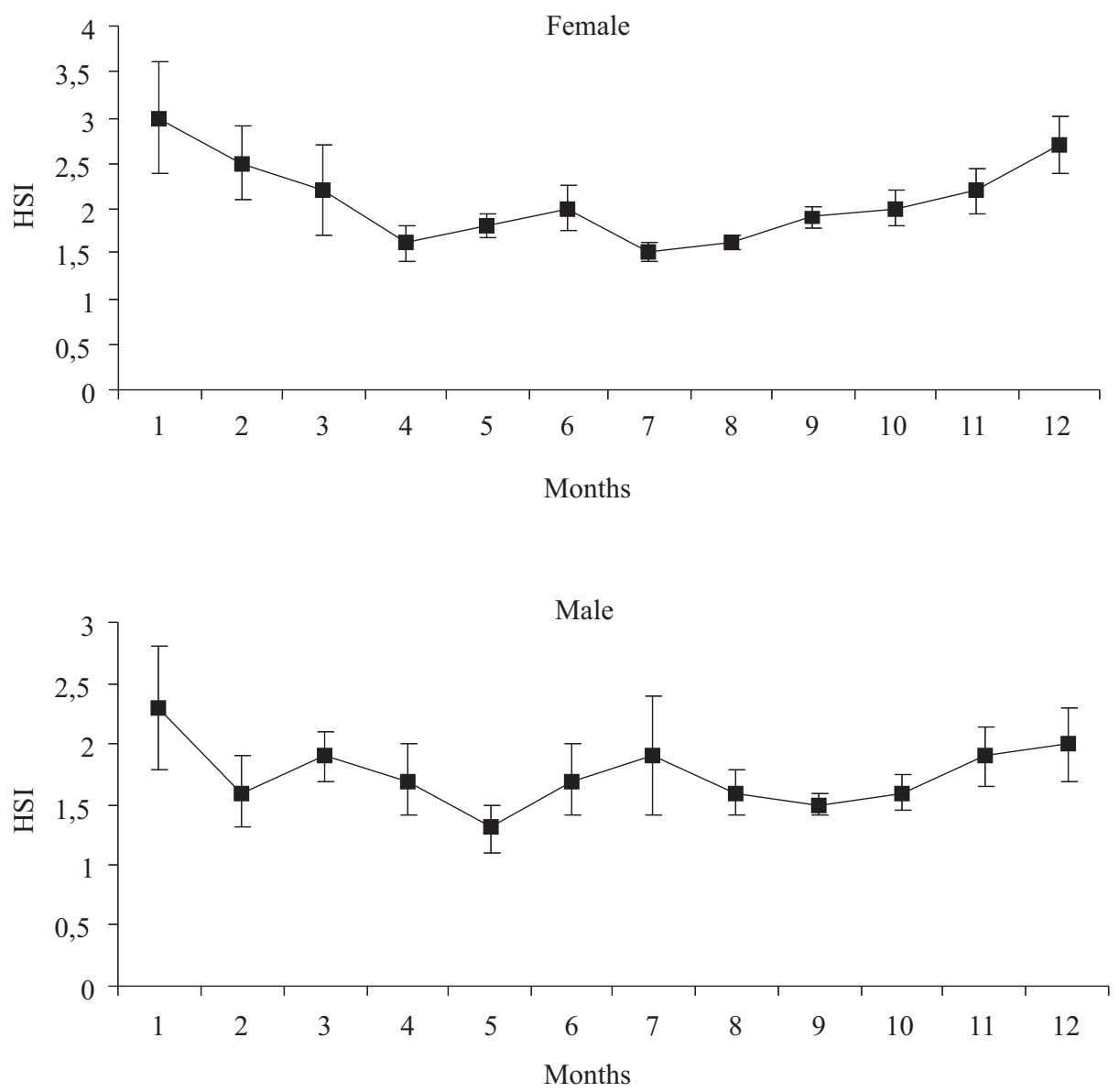

Fig. 6. Monthly hepatosomatic index (HSI) of (a) female and (b) male of Gobius paganellus from the south-eastern Black Sea $($ Mean \pm SE)

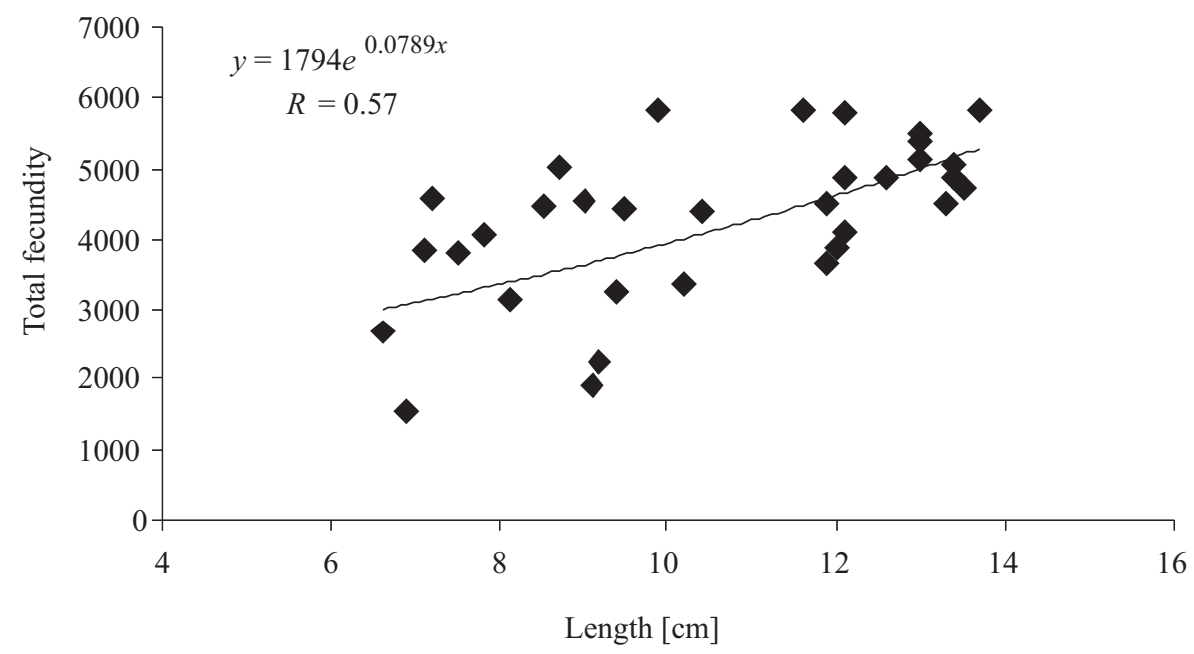

Fig. 7. Total fecundity-total length relationship of Gobius paganellus from the south-eastern Black Sea 
were among the more frequent $(F>60 \%)$ and abundant prey items $(N>70 \% ; W>30 \%)$. Based on the main food index $\left(I_{\mathrm{MF}}\right)$, Gammaridae, Natantia, and Brachyura were the main food taxa. An ontogenetic shift was observed in diet of G. paganellus: the most preferred prey of young fish were decapod larvae and mysids, whereas large fish fed on Gammaridae, Natantia, and Brachyura (Fig. 8).

No seasonal variation was observed in diet, but the feeding intensity varied seasonally. The fullness index $\left(I_{F}\right)$ was significantly lower in autumn, compared to other seasons (Fig. 9).

\section{DISCUSSION}

Age, growth, reproduction, and feeding habits of the Black Sea population of G. paganellus have never been investigated until now. The maximum size of the specimens recorded in this study was similar to the Atlantic populations (Azevedo and Simas 2000), as well as the longevity estimated for both sexes (7-10 years) (Miller 1961, Dunne 1978). Other European Gobius species shown high longevity and variability (2-10 years) (Vaas et al. 1975, Fabi and Giannetti 1985, Nash 1984, Vesey and Langford 1985, Joyeux et al. 1991, Arruda et al. 1993, Sasal et al. 1996,

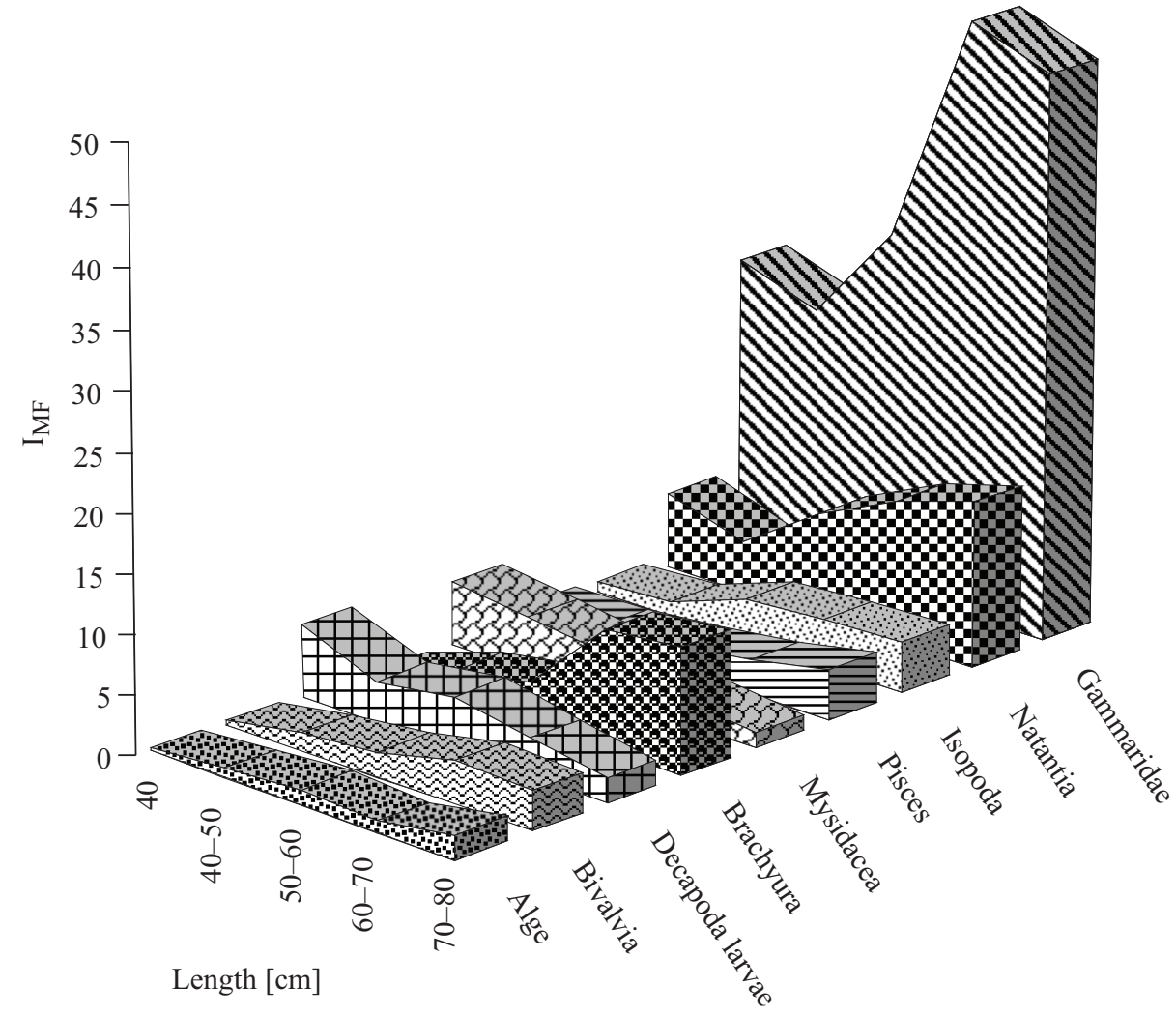

Fig. 8. Food of Gobius paganellus from the south-eastern Black Sea

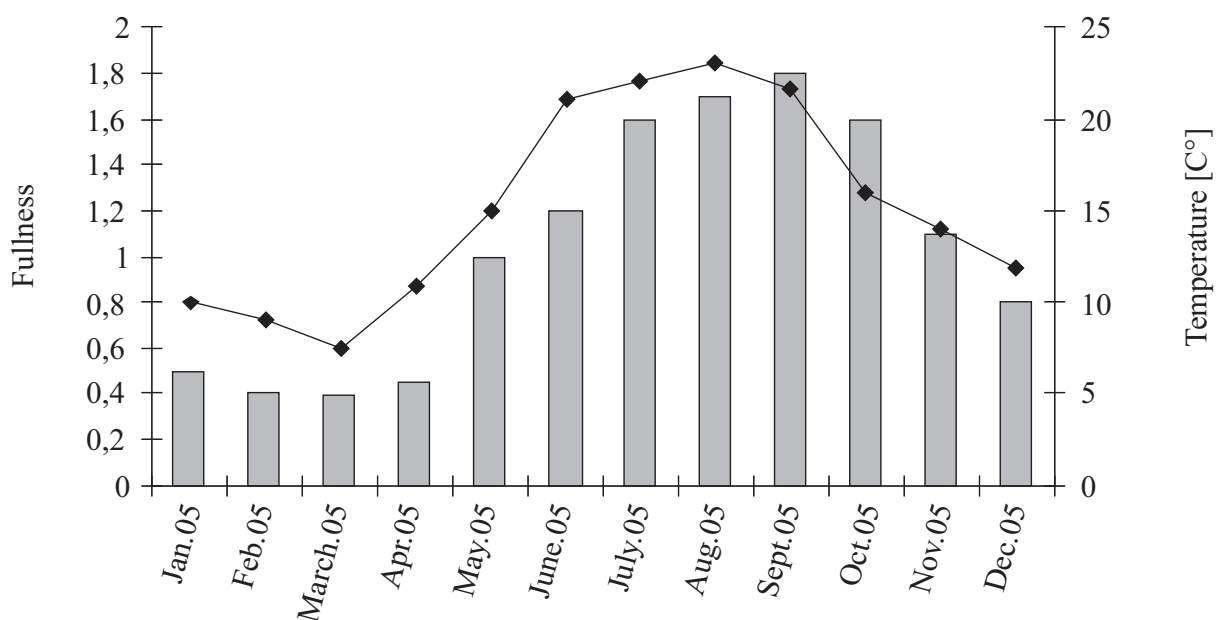

Fig. 9. Monthly fullness index $\left(\mathrm{I}_{\mathrm{F}}\right)(\square)$ of Gobius paganellus from the south-eastern Black Sea, and monthly temperature of sea water 
Silva and Gordo 1997, Kovačić 2001, 2006). The von Bertalanffy growth parameter $L_{\infty}$ of $G$. paganellus was similar to previous studies in north-east Atlantic and Mediterranean Sea. Conversely, instantaneous growth rate $(k)$ and growth performance $(\varphi$ ) of $G$. paganellus were smaller than populations of Azores (Azevedo and Simas, 2000) but similar to north-east Atlantic population (Miller 1961, Dunne 1978).

The sex ratio was similar to other gobiids, such as G. niger (see: Nash 1984), G. roulei (see: Kovačić 2001), and G. vittatus (see: Kovačić 2007). In the present study, the Black Sea population of G. paganellus attained sexual maturity early, as gonad development began in the first year of life, as previously reported by Azevedo and Simas (2000). Instead, sexual maturity of G. paganellus in the north-east Atlantic was reached in the second year of age (Miller 1961) or in the third one (Dunne 1978). The spawning period was from March to June in the Black Sea, like all other Gobius species from the north-east Atlantic and Mediterranean Sea (Miller 1961, Gibson 1970, Vaas et al. 1975, Dunne 1978, Nash 1984, Vesey and Langford 1985, Joyeux et al. 1991, Arruda et al. 1993, Silva and Gordo 1997, Azevedo and Simas 2000, Kovačić 2001, 2007). The annual variation of hepatosomatic index showed that the energy storage decreased during the spawning season and increased afterwards. A marked reduction in liver mass was reported at the beginning or during the breeding season by Joyeux et al. (1992), Fouda et al. (1993), and Kovačić (2007). Fecundity of the Black Sea population of the rock goby was lower than that from the north-eastern Atlantic (Miller 1961).

Crustaceans were the main prey items of G. paganellus in the studied area, in agreement with other studies carries out in Mediterranean and north-eastern Atlantic (Gibson 1972, Dunne 1978, Azevedo and Simas 2000, Maze 2004). However, according to Costa (1988), the most frequent food items in the population from the Tagus Estuary were polychaetes. A small amount of algae was also found in the stomach contents. Azevedo and Simas (2000) suggested that algal material is ingested accidentally, together with other usual prey. It fed on benthic mobile fauna, smaller specimens prefer meiofauna and macrofauna, the larger ones generally preyed on macrofauna. Ontogenetic diet shift of the rock goby was similar to that reported from northern Spain population, without seasonal differences (Maze 2004). It is generally found that in gobies the feeding intensity is strongly related to the sea water temperature (Collins 1981, 1982, Joyeux et al. 1991, Kovačić 2001, 2007). A similar finding was also observed in the present study, as G. paganellus showed a low feeding intensity in winter and spring when the sea water temperature was at the lowest level of the year.

Bio-ecological studies on gobies showed that this small fishes have an important function in coastal rocky habitats. But difficulties on sampling with diving restricted studies on this topic.

\section{ACKNOWLEDGMENTS}

This study was supported by the Karadeniz Technical University Research Grant No. 2005.117.001.3. We thank to two anonymous reviewers for valuable comments.

\section{REFERENCES}

Arruda L., Azevedo J.N., Neto A.I. 1993. Abundance, agestructure and growth, and reproduction of gobies (Pisces; Gobiidae) in the Ria de Aveiro Lagoon (Portugal). Estuarine, coastal and Shelf Science 37: 509-523. DOI: 10.1006/ecss.1993.1070.

Azevedo J.M.N., Simas A.M.V. 2000. Age and growth, reproduction and diet of a sublittoral population of the rock goby Gobius paganellus (Teleostei, Gobiidae). Hydrobiologia 440: 129-135. DOI: 10.1023/A:1004102723234.

Collins S.P. 1981. Littoral and benthic investigations on the west coast of Ireland-XIII. The biology of Gobiusculus flavescens (Fabricius) on the Connemara coast. Proceedings of the Royal Irish Academy B 81 (7): 63-87.

Collins S.P. 1982. Littoral and benthic investigations on the west coast of Ireland-XIV. The biology of the painted goby, Pomatoschistus pictus (Malm) (Teleostei: Gobiidae) on the Connemara coast. Proceedings of the Royal Irish Academy B 82 (7): 21-37.

Costa M. 1988. Écologie alimentaire des poissons de l'estuarie du Tage. Cybium 12: 301-320.

Dunne J. 1978. Littoral and benthic investigations on the west coast of Ireland - IX (Section A: Faunistic and ecological studies). The biology of the rock-goby, Gobius paganellus L., at Carna. Proceedings Royal Irish Academy B 78 (12): 179-191.

Engin S., Turan D., Kovačić M. 2007. First Record of the RedMouthed Goby, Gobius cruentatus (Pisces: Gobiidae), in the Black Sea. Cybium 31: 87-88.

Fabi G., Gianetti G. 1985. Growth parameters of the black goby (Gobius niger L.) in the Adriatic Sea, based on otoliths reading. Rapport du Congrès de la Commission Internationale pour 1'Exploration Scientifique la Mer Méditerranée 29: 87-90.

Fouda M.M., Hanna M.Y., Fouda F.M. 1993. Reproductive biology of the Red Sea goby, Silhouettea aegyptia, and a Mediterranean goby, Pomatoschistus marmoratus, in Lake Timsah, Suez Canal. Journal of Fish Biology 43: 139-151. DOI: $10.1111 / j .1095-8649.1993 . t b 00417 . x$.

Fricke R., Bilecenoglu M., Sarı H.M. 2007. Annotated checklist of fish and lamprey species of Turkey, including a Red List of threatened and declining species. Stuttgarter Beiträge zur Naturkunde A 706: 1-169.

Gibson R.N. 1970. Observations on the biology of the giant goby Gobius cobitis Pallas. Journal of Fish Biology 3: 281-288. DOI: 10.1111/j.1095-8649.1970.tb03286.x.

Gibson R.N. 1972. The vertical distribution and feeding relationships of intertidal fish on the Atlantic coast of France. Journal of Animal Ecology 41: 187-207.

Hureau J.C. 1970. Biologie comparée de quelques poissons antartiques (Nototheniidae). Bulletin de l'Institut Océanographique de Monaco 68: 1-244. 
Joyeux J.-C., Bouchereau J.-L., Tomasini J.-A. 1991. La reproduction de Gobius niger (Pisces, Gobiidae) dans la lagune de Mauguio, France. Rapports gonosomatiques, fécondités, ponte, œufs et larves. Vie et milieu 41: 97-106.

Joyeux J.-C., Tomasini J.-A., Bouchereau J.-L. 1992. Modalités de la reproduction de Gobius niger (Teleostei, Gobiidae) dans une lagune méditerranéenne. Vie et milieu 42: 1-13.

Kovačić M. 2001. The biology of Roule's goby in the Kvarner area, northern Adriatic Sea. Journal of Fish Biology 59: 795-809. DOI: 10.1111/j.1095-8649.2001.tb00150.x.

Kovačić M. 2006. Age structure, growth and mortality of the striped goby, Gobius vittatus (Gobiidae) in the northern Adriatic Sea. Scientia Marina 70: 635-641. DOI: 10.3989/scimar.2006.70n4635.

Kovačić M. 2007. Reproductive biology of the striped goby, Gobius vittatus (Gobiidae) in the northern Adriatic Sea. Scientia Marina 71: 145-151. DOI: 10.3989/scimar.2007.71n1145.

Kovačić M., Engin S. 2008. Two new species of neogobius (Gobiidae) from north-eastern Turkey. Cybium 32: 73-80.

Mazé R.A. 2004. Seasonal and ontogenetic diet shifts in an intertidal population of Gobius paganellus (Teleostei, Gobiidae) from the Cantabrian coast. Vie et milieu 54: 1-6.

Miller P.J. 1961. Age, growth, and reproduction of the rock goby Gobius paganellus L., in the Isle of Man. Journal of the Marine Biological Association of the United Kingdom 41: 737-769. DOI: 10.1017/S0025315400016283.

Miller P.J. 1986. Gobiidae. Pp. 1019-1085. In: Whitehead P.J.P., Bauchot M.-L., Hureau J.-C., Nielsen J., Tortonese E. (eds.) Fishes of the Northeastern Atlantic and the Mediterranean. Vol. 3. UNESCO, Paris.

Nash R.D.M. 1984. Aspects of the biology of the black goby, Gobius niger L., in Oslofjorden, Norway. Sarsia 69: 55-61.
Patzner R.A., Seiwald M., Angerer S., Ferrero E.A., Giulianini P.G. 1991. Genital system and reproductive cycle of the male grass goby, Zosterisessor ophiocephalus (Teleostei, Gobiidae) in the Northern Adriatic Sea. Zoologischer Anzeiger 226: 205-219.

Ricker W.E. 1975. Computation and interpretation of biological statistics of fish populations. Bulletin Fisheries Research Board of Canada 191: 1-382.

Sasal P., Faliex E., Morand S. 1996. Population structure of Gobius bucchichii in a Mediterranean marine reserve and in unprotected area. Journal of Fish Biology 49: 352-356. DOI: 10.1111/j.1095-8649.1996.tb00029.x.

Silva M.N., Gordo L.S. 1997. Age, growth and reproduction of the black goby, Gobius niger, from Óbidos Lagoon, Portugal. Cahiers de Biologie Marine 38: 175-180.

Vaas K.F., Vlasblom A.G., Koeijer P. 1975. Studies on the black goby (Gobius niger, Gobiidae, Pisces) in the Veerse Meer, SW Netherlands. Netherlands Journal of Sea Research 9: 56-68. DOI: 10.1016/0077-7579(75)90022-8.

Vesey G., Langford T.E. 1985. The biology of the black goby, Gobius niger L. in an English south-coast bay. Journal of Fish Biology 27: 417-429. DOI: 10.1111/j.1095-8649.1985.tb03190.x.

Zander C.D. 1982. Feeding ecology of littoral gobiid and blennioid fish of the Banylus area (Mediterranean Sea). I. Main food and trophic dimension of niche and ecotope. Vie et milieu 32: 1-10.

Received: 4 February 2008

Accepted: 15 July 2009

Published electronically: 10 December 2009 